\title{
PENGARUH IMPLEMENTASI TOTAL QUALITY MANAGEMENT TERHADAP KEPUASAN PELANGGAN
}

\author{
Arifin Al Amiri M1 \\ Kastawan Mandala ${ }^{2}$ \\ ${ }^{1,2}$ Fakultas Ekonomi dan Bisnis Universitas Udayana, Bali, Indonesia \\ email: arifinalamiiri@gmail.com
}

\begin{abstract}
ABSTRAK
Penelitian ini dilakukan di Kober Mie Setan. Jumlah sampel yang diambil sebanyak 150 orang pelanggan Kober Mie, dengan metode non probability sampling. Pengumpulan data dilakukan melalui penyebaran kuesioner. Teknik analisis data yang digunakan adalah regresi linier berganda.Berdasarkan hasil analisis ditemukan bahwa variabel fokus pada pelanggan, obsesi pada kualitas, kerjasama tim dan perbaikan berkesinambungan secara simultan berpengaruh signifikan terhadap kepuasan pelanggan. Hasil pengujian hipotesis uji parsial diketahui bahwa masing-masing variabel fokus pada pelanggan, obsesi pada kualitas, kerjasama tim dan perbaikan berkesinambungan berpengaruh positif signifikan terhadap kepuasan pelanggan. Dari hasil uji parsial diketahui bahwa variabel fokus pada pelanggan merupakan variabel yang paling berpengaruh dominan terhadap kepuasan pelanggan. Nilai koefisien determinasi sebesar 0,731 menunjukkan bahwa 73,1 persen variasi kepuasan pelanggan bisa dijelaskan oleh empat variabel independen yang digunakan dalam persamaan regresi, sedangkan sisasnya sebesar 26,9 persen dijelaskan oleh variabel lain diluar keempat variabel yang digunakan dalam penelitian ini.
\end{abstract}

Kata kunci: kepuasan pelanggan, manajemen operasi, total quality management

\section{ABSTRACT}

This research was conducted at Kober Mie Setan. The number of samples taken as many as 150 people Kober Mie customer. Data collection done through questionnaires. Based on the results of the analysis it wasfound that the variable focus on customers, obsession with quality, teamwork and continuous improvement simultaneously had significant effect on customer satisfaction. The results of testing the partial test hypothesis revealed that each variable focused on the customer, obsession with quality, teamwork and continuous improvement had a significant positive effect customer satisfaction. From the results of the partial test it is known that the focus variable on the customer is the most dominant variable affecting customer satisfaction. The coefficient determination of 0.731 shows that 73.1 percent variations in customer satisfaction can be explained by four independent variables used the regression equation, while the sisas are 26.9 percent explained other variables outside the four variables used this study.

Keywords: customer satisfaction, operations management, total quality management 


\section{PENDAHULUAN}

Bali merupakan provinsi dengan jumlah penduduk yang padat, laju pertumbuhan penduduk Bali yang rata-rata mencapai 2,15 persen berada di atas angka rata-rata nasional. Perkembangan ini membuat jumlah penduduk Bali saat ini telah mencapai lebih dari 4,2 juta di tahun 2018 disampaikan Gubernur Bali I Made Mangku Pastika, M.M. Hal ini memberikan tantangan tersendiri bagi pembangunan Bali di masa depan. Pada sisi lain, laju pertumbuhan penduduk yang demikian pesat mengandung peluang bisni yang dapat dimanfaatkan. Dewasa ini bisnis yang banyak dikembangkan guna menunjang kebutuhan penduduk adalah bisnis kuliner yaitu makanan dan minuman (Amalina, 2015). Industri kuliner merupakan salah satu bagian dari industri kreatif yang saat ini menjadi target yang akan dikembangkan oleh pemerintah, karena dipandang semakin penting dalam mendukung peningkatan perekonomian global dan nasional. Pertumbuhan ekspor industri kreatif secara global tumbuh secara signifikan. Sebagai contoh, data dari negara berkembang menunjukkan bahwa pertumbuhan ekspor dari sektor industri kreatif adalah yang terbesar yaitu 33,19 persen, demikian disampaikan Marie Pangestu, Menteri Pariwisata \& Ekonomi Kreatif pada Kabinet Indonesia Bersatu dalam suatu kesempatan di Bali pada tahun 2013. Pada kesempatan lain, Menteri Perindustrian Saleh Husin menyatakan bahwa industri kreatif merupakan salah satu pilar dalam membangun ekonomi nasional, karena mampu menciptakan sumber daya manusia yang berdaya saing di era globalisasi, sekaligus mensejahterakan masyarakat, yang membuatnya dipandang sangat strategis. Menperin menyampaikan hal tersebut pada peresmian Konferensi Internasional Industri Kreatif atau International Conference Creative Industry (ICCI) 2015 di Denpasar, Bali.

Industri kreatif merupakan industri yang memanfaatkan kreativitas, keterampilan serta bakat individu untuk menghasilkan dan memberdayakan daya kreasi dan daya cipta individu tersebut. Pengembangan industri kreatif saat ini terfokus pada 15 subsektor industri kreatif, yakni arsitektur, desain, fesyen, film, video dan fotografi, kerajinan, layanan komputer dan peranti lunak, musik, pasar barang seni, penerbitan dan percetakan, periklanan, permainan interaktif, riset dan pengembangan, seni pertunjukan, televisi dan radio, serta kuliner.

Industri makanan dan minuman (kuliner) itu sendiri terdiri dari banyak jenis, seperti industri rumah makan, minuman kemasan, bumbu dapur, bahan kue, dan sebagainya. Beragamnya bisnis sektor kuliner ini merupakan tantangan sekaligus sangat menjanjikan atau membuka peluang bagi para produsen atau para pengusaha untuk membuat inovasi dalam bidang bisnis kuliner.

Kota Denpasar merupakan salah satu kota besar di Indonesia sekaligus menjadi ibu kota provinsi Bali. Selain mempunyai banyak objek wisata alam maupun objek wisata sejarah, kota Denpasar pun menawarkan pengalaman berwisata yang menarik yaitu wisata belanja pakaian dan sovenir (factory outlet) dan wisata kuliner. Khusus wisata kuliner, Denpasar banyak menawarkan hidangan-hidangan kuliner yang menarik mulai dari menu tradisional sampai internasional. Hal inilah yang mendorong banyak pelaku bisnis berlomba-lomba membuka usaha di bidang kuliner. Bentuk usaha kuliner di kota Denpasar sangat beragam mulai dari kafe atau coffee shop, restoran (food court). Banyaknya 
wisatawan lokal dan wisatawan asing yang datang ke kota Denpasar setiap harinya membuat bisnis kuliner di kota ini sangat menjanjikan dan menguntungkan. Konsekwensi logis dari hal ini, berdampak pada makin banyaknya para pelaku usaha yang terus berinovasi dan membuat ide-ide baru yang bertujan untuk menarik para pelanggannya. Ide atau inovasi bisnis kuliner yang sedang naik daun (booming) dan menarik perhatian banyak masyarakat di kota Denpasar saat ini adalah Kober Mie Setan. Dahulu, mie bukan pilihan bersantap di restoran, tetapi semenjak Kober Mie Setan dibuka di Bedugul tibatiba jadi viral dan selalu diserbu pengunjung.

Dalam usaha bisnis kuliner diperlukan adanya keistimewaan dan keunikan yang diberikan kepada para konsumen agar dapat menarik minat pembelian mereka. Saat ini rumah makan yang menawarkan jenis makanan mie pedas khususnya di Denpasar ada beberapa rumah makan seperti Mie Rampok, Kober Mie Setan. Mie Ndower, Mie Obonk Barito dan Cwie Mie OSTO. Khusus untuk kuliner Kober Mie Setan memang menyasar kalangan mahasiswa dan pelajar. Harga yang relatif murah dipadu dengan suasana bersantap khas orang muda menjadi konsep utama Kober Mie Setan. Cita rasa yang pedas merupakan ciri khas Kober Mie Setan ini yang juga menjadi menarik perhatian masyarakat, sehingga membuat tempat ini menjadi incaran para penikmat kuliner pedas. Pada sisi lain, bukan hanya rasa pedasnya saja yang menarik perhatian pelanggan, namun list menu yang cukup unik yaitu Mie Iblis dan Mie Setan, serta jenis minuman sebagai pendamping mie juga menggunakan nama-nama unik seperti Genderuwo, Pocong, Sundel Bolong, Kuntilanak, serta Tuyul juga membuat rasa ingin tahu dan penasaran masyarakat meningkat.

Manajemen Kober Mie Setan pulau kawe masih belum maksimal dalam pemberian dan pelaksanaan pelayanan. Hal tersebut menimbulkan dampak terhadap kepuasan pelanggan Kober Mie Setan. Menurut beberapa review dari pelanggan di Instagram, foursquare.com dan Facebook Kober Mie Setan Pulau Kawe reviewer menyampaikan beberapa keluhan yang dirasakan.

Tabel 1.

Daftar Keluhan Kober Mie Setan Pulau Kawe

\begin{tabular}{clc}
\hline No. & \multicolumn{1}{c}{ Keluhan } & Jumlah \\
\hline 1. & Antrian yang terlalu panjang & 8 \\
2. & Pesanan yang datang terlalu lama & 5 \\
3. & Tempat parkir yang kurang luas & 3 \\
4. & Pelayanan yang kurang cepat & 3 \\
5. & Toilet yang kotor & 1 \\
\hline
\end{tabular}

Sumber: Data sekunder, 2018

Daftar keluhan yang ditunjukkan pada Tabel 1. menjadi bahan evaluasi bagi Kober Mie Setan Pulau Kawe untuk lebih memperhatikan kualitas perusahaannya agar pengunjung merasa puas. Pada hakikatnya tujuan dari suatu bisnis adalah untuk memuaskan dan mempertahankan para pelanggan. Apabila kualitas perusahaan rendah maka pelanggan akan tidak puas dan beralih ke pesaing. Cara untuk dapat memperbaiki kualitas layanan di Kober Mie Setan adalah dengan pendekatan yang dapat membantu manajemen menghasilkan kualitas layanan 
terbaik yaitu dengan menerapkan prinsip Total Quality Management (TQM) melalui langkah-langkah yang tepat.

Total Quality Management merupakan suatu pendekatan yang berorientasi pada masyarakat atau pelanggan dengan memperkenalkan perubahan manajemen secara sistematik dan perbaikan terus menerus terhadap proses, dan pelayanan. Menurut (Tjiptono dan Diana, 2014), TQM merupakan suatu pendekatan dalam mengorganisasikan manajemen kerja untuk memaksimumkan daya saing perusahaan melalui perbaikan terus menerus atas produk, jasa, manusia (SDM), proses dan lingkungannya. Sementara itu TQM adalah salah satu pola manajemen organisasi yang berisi seperangkat prosedur yang dapat digunakan oleh setiap orang dalam upaya memperbaiki kinerja secara terus menerus. Total Quality Management bukan merupakan tujuan akhir perusahaan atau organisasi, melainkan suatu cara untuk mencapai sasaran organisasi (Andrianto dan Edo, 2011). Dasar pemikiran perlunya penerapan Total Quality Management adalah agar perusahaan dapat bersaing dan unggul dalam persaingan global dengan menghasilkan kualitas terbaik. Total Quality Management menekankan pada komitmen oleh manajemen untuk memiliki terus-menerus menuju keungggulan dalam segala aspek barang dan jasa yang penting bagi pelanggan.

Secara umum, sebenarnya prinsip Total Quality Management telah di implementasikan pada pengelolaan rumah makan Kober Mie Setan, salah satu contohnya adalah dengan cara mengatur keseluruhan kualitas produk yang ditawarkan. Berkaitan dengan hal ini, menurut (Tjiptono dan Diana, 2014) terdapat 10 karakteristik Total Quality Management, yaitu sebagai berikut : 1) Fokus pada pelanggan, 2) Memiliki obsesi yang tinggi terhadap kualitas, 3) Menggunakan pendekatan ilmiah dalam pengambilan keputusan dan pemecahan masalah, 4) Memiliki komitmen jangka panjang, 5) Membutuhkan kerjasama tim (teamwork), 6) Memperbaiki proses secara berkesinambungan, 7) Menyelenggarakan pendidikan dan pelatihan, 8) Memberikan kebebasan yang terkendali, 9) Memiliki kesatuan tujuan, dan 10) Adanya keterlibatan dan pemberdayaan karyawan.

Dari 10 karakteristik TQM tersebut, untuk kasus usaha bisnis kuliner seperti Kobar Mie Setan ada 4 karakteristik yang menarik untuk dikaji lebih mendalam, yaitu:1) fokus pada pelanggan, 2) memiliki obsesi terhadap kualitas, 3) kerjasama tim (teamwork), dan 4) perbaikan proses secara berkesinambungan. Hal ini penting karena merupakan variabel yang representatif untuk mengukur pengaruh aplikasi Total Quality Management terhadap kepuasan pelanggan, karena keempat karakteristik tersebutlah yang dapat langsung dilihat serta dirasakan oleh pelanggan.

Beberapa peneliti terdahulu telah melakukan penelitian mengenai pengaruh Total Quality Management terhadap kepuasan pelanggan. Menurut Kurniawati (2011) variabel fokus pada pelanggan, obsesi terhadap kualitas dan kerjasama tim berpengaruh secara positif signifikan secara parsial terhadap kepuasan pelanggan pada Hotel Pondok Asri Tawangmangu. Menurut Timor et al. (2018) perbaikan mutu sekolah berkelanjutan berpengaruh positif terhadap kepuasan pelanggan. Hasil yang berbeda ditemukan dalam penelitian Citraluki (2016) menyatakan bahwa variabel obsesi kualitas tidak memiliki dampak yang signifikan pada 
kepuasan pelanggan pada Indomaret sekecamatan Kertasura. Hasil yang negatif juga ditemukan pada penelitian yang dilakukan oleh Mahami (2015) dalam penelitian tersebut ditemukan bahwa kerjasama tim tidak berpengaruh signifikan terhadap kepuasan pelanggan.

Tujuan penelitian ini yakni untuk menjelaskan pengaruh variabel fokus, variabel obsesi, kerjasama tim, dan perbaikan berkesinambungan pada pelanggan terhadap kepuasan pelanggan kober mie setan. Penelitian ini diharapkan dapat menambah referensi, informasi dan wawasan dalam mendukung proses pengelolaan usaha bidang kuliner yang lebih efektif, efisien dan memuaskan, serta dapat menjadi rujukan atau pembanding untuk penelitian-penelitian selanjutnya yang berkaitan dengan Total Quality Management pada umumnya, dan perbaikan proses pengelolaan atau manajemen bisnis bidang kuliner khususnya.

Penelitian ini diharapkan dapat menambah pengetahuan dan pemahaman mahasiswa mengenai pengaplikasian teori yang telah diperoleh selama menempu pendidikan di perguruan tinggi terutama mengenai permasalahan yang terkait dengan Total Quality Management. Bagi perusahaan tempat penelitian ini dilaksanakan Kober Mie Setan, hasil yang diperoleh dari penelitian ini diharapkan dapat dijadikan sebagai bahan masukan untuk meningkatkan kualitas pelayanan pada pelanggan mereka.

Kerangka pemikiran perlunya Total Quality Management sangatlah sedarhana, yakni cara terbaik agar dapat bersaing dan unggul dalam persaingan global ataupun lokal dengan menghasilkan kualitas terbaik. Kepuasan pelangan dapat terbentuk saat pelangan merasa puas akan produk dan layanan yang dikonsumsinya. Terdapat 10 karakteristik Total Quality Management dari kajian pustaka yang sudah dijelaskan, namun hanya 4 karakteristik yang digunakan yaitu: fokus pada pelanggan, obsesi terhadap kualitas, kerjasama tim (teamwork) dan perbaikan proses secara berkesinambungan, karena mengukur pengaruh Total Quality Management terhadap kepuasan pelanggan, empat katakteristik tersebut yang tampaknya langsung terlihat serta dirasakan oleh pelanggan. Berdasarkan kajian dari hasil penelitian-penelitian sebelumnya, maka kerangka konseptual dapat disajikan pada Gambar 1. berikut.

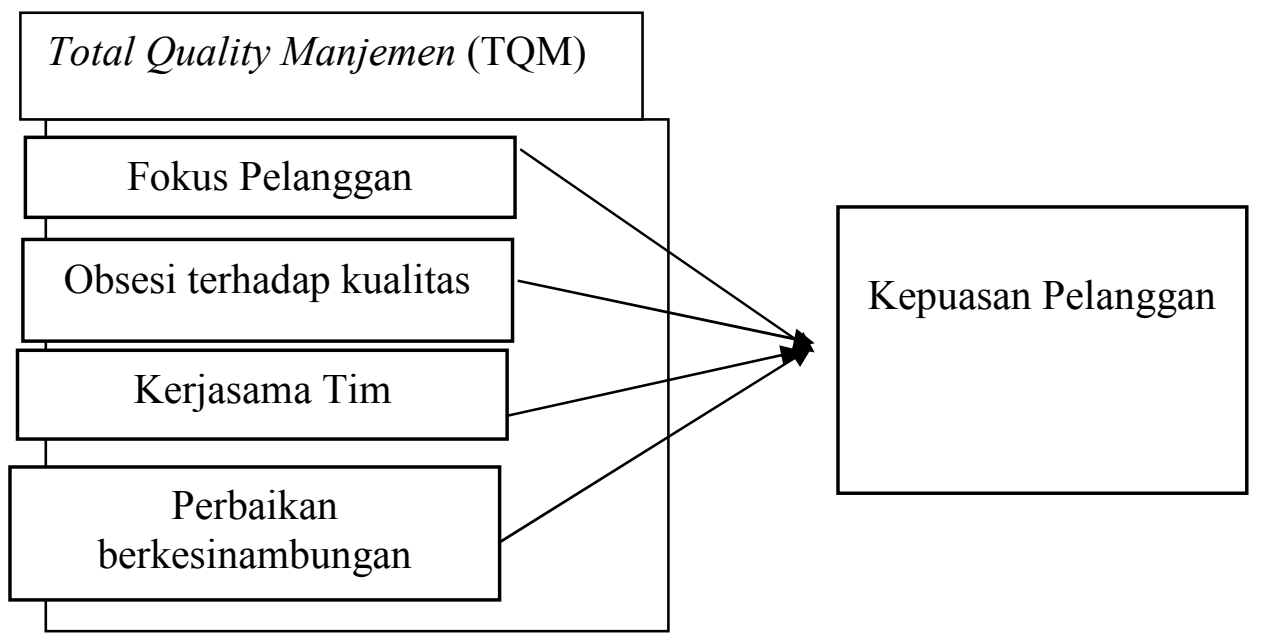

Gambar 1. Kerangka Konseptual Penelitian 
Total Quality Management merupakan suatu pendekatan yang berorientasi pada masyarakat atau pelanggan dengan memperkenalkan perubahan manajemen secara sistematik dan perbaikan terus menerus terhadap proses, dan pelayanan. Menurut (Tjiptono dan Diana, 2014), TQM merupakan suatu pendekatan dalam mengorganisasikan manajemen kerja untuk memaksimumkan daya saing perusahaan melalui perbaikan terus menerus atas produk, jasa, manusia (SDM), proses dan lingkungannya. Sementara itu TQM adalah salah satu pola manajemen organisasi yang berisi seperangkat prosedur yang dapat digunakan oleh setiap orang dalam upaya memperbaiki kinerja secara terus menerus. Total Quality Management bukan merupakan tujuan akhir perusahaan atau organisasi, melainkan suatu cara untuk mencapai sasaran organisasi (Andrianto dan Edo, 2011). Dasar pemikiran perlunya penerapan Total Quality Management adalah agar perusahaan dapat bersaing dan unggul dalam persaingan global dengan menghasilkan kualitas terbaik. Total Quality Management menekankan pada komitmen oleh manajemen untuk memiliki terus-menerus menuju keungggulan dalam segala aspek barang dan jasa yang penting bagi pelanggan.

Secara umum, sebenarnya prinsip Total Quality Management telah di implementasikan pada pengelolaan rumah makan Kober Mie Setan, salah satu contohnya adalah dengan cara mengatur keseluruhan kualitas produk yang ditawarkan. Berkaitan dengan hal ini, menurut (Tjiptono dan Diana, 2014) terdapat 10 karakteristik Total Quality Management, yaitu sebagai berikut : 1) Fokus pada pelanggan, 2) Memiliki obsesi yang tinggi terhadap kualitas, 3) Menggunakan pendekatan ilmiah dalam pengambilan keputusan dan pemecahan masalah, 4) Memiliki komitmen jangka panjang, 5) Membutuhkan kerjasama tim (teamwork), 6) Memperbaiki proses secara berkesinambungan, 7) Menyelenggarakan pendidikan dan pelatihan, 8) Memberikan kebebasan yang terkendali, 9) Memiliki kesatuan tujuan, dan 10) Adanya keterlibatan dan pemberdayaan karyawan.

Dari 10 karakteristik TQM tersebut, untuk kasus usaha bisnis kuliner seperti Kobar Mie Setan ada 4 karakteristik yang menarik untuk dikaji lebih mendalam, yaitu:1) fokus pada pelanggan, 2) memiliki obsesi terhadap kualitas, 3) kerjasama tim (teamwork), dan 4) perbaikan proses secara berkesinambungan. Hal ini penting karena merupakan variabel yang representatif untuk mengukur pengaruh aplikasi Total Quality Management terhadap kepuasan pelanggan, karena keempat karakteristik tersebutlah yang dapat langsung dilihat serta dirasakan oleh pelanggan.

Beberapa peneliti terdahulu telah melakukan penelitian mengenai pengaruh Total Quality Management terhadap kepuasan pelanggan. Menurut Kurniawati (2011) variabel fokus pada pelanggan, obsesi terhadap kualitas dan kerjasama tim berpengaruh secara positif signifikan secara parsial terhadap kepuasan pelanggan pada Hotel Pondok Asri Tawangmangu. Menurut Timor et al. (2018) perbaikan mutu sekolah berkelanjutan berpengaruh positif terhadap kepuasan pelanggan. Hasil yang berbeda ditemukan dalam penelitian Citraluki (2016) menyatakan bahwa variabel obsesi kualitas tidak memiliki dampak yang signifikan pada kepuasan pelanggan pada Indomaret sekecamatan Kertasura. Hasil yang negatif juga ditemukan pada penelitian yang dilakukan oleh Mahami (2015) dalam 
penelitian tersebut ditemukan bahwa kerjasama tim tidak berpengaruh signifikan terhadap kepuasan pelanggan.

Fokus pelanggan merupakan hal yang sangat penting yang harus dilakukan oleh perusahaan untuk lebih memberikan kesan yang baik kepada pelanggan dan membuat pelanggan merasa puas. Interaksi yang intensif kepada pelanggan harus dilakukan agar pelanggan lebih mengenal produk yang dijual atau yang dipasarkan agar menimbulkan rasa puas di benak pelanggan. Bahwa kekuatan dari perusahaan yang terdapat di dalam implentasi manajemen kualitasnya, terletak pada customer focus. Menyimpulkan bahwa pelanggan merupakan sosok yang harus dilayani dan diperhatikan apa yang menjadi kebutuhan dan harapannya. Setiap organisasi yang menerapkan Total Quality Management harus mengetahui, mengidentifikasi, serta menganalisis kebutuhan dan harapan para pelanggan. Hal ini berarti bahwa produk atau jasa yang diberikan harus sesuai dengan keinginan dan harapan para pelanggan.

Dalam penelitian Jaafreh (2012) strategi bisnis yang futuristik selalu mengedepankan posisi pelanggan sebagai dimensi yang lebih tinggi dan berkuasa. Layanan terbaik bukan lahir dari rumusan rapat para manajer dan direktur dari sebuah perusahaan. Layanan terbaik juga bukan rumusan strategi bisnis yang sudah direncanakan. Namun layanan terbaik adalah sejauh mana memahami keinginan pelanggan pada waktu kemarin, saat ini, dan masa yang akan datang. Telah dikonfirmasi kemudian dalam penelitian Ooi (2011) bahwa dimensi dari customer focus berhubungan erat dengan customer satisfaction dan Total Quality Management.

Berdasarkan penelitian yang dilakukan oleh Jaafreh (2012), Efendi dan Mandala (2018) menyimpulkan bahwa fokus pada pelanggan berpengaruh positif terhadap kepuasan pelanggan. Berdasarkan uraian tersebut dapat dirumuskan hipotesis sebagai berikut:

$\mathrm{H}_{1}$ : Fokus pada pelanggan berpengaruh positif signifikan terhadap kepuasan pelanggan.

Dalam upaya meningkatkan mutu perusahaan salah satu usaha yang dapat dilakukan adalah dengan meningkatkan mutu produk atau jasa yang ditawarkan sehingga produk yang ditawarkan tersebut bisa memenuhi harapan atau keinginan pelanggan Wuryanti (2013) . Kualitas produk atau jasa yang baik akan menciptakan image yang baik pula di benak pelanggan. Dalam penelitian Mosahab (2014) menyebutkan bahwa dengan kualitas yang telah ditetapkan perusahaan, organisasi harus terobsesi untuk memenuhi atau melebihi apa yang ditentukan tersebut.

Penelitian yang dilakukan oleh Lopresti (2006) dan Mononimbar (2013) Citraluki et al. (2016), Efendi dan Mandala (2018) menyatakan bahwa obsesi terhadap kualitas tidak berpengaruh terhadap kepuasan pelanggan. Berdasarkan uraian tersebut dapat dirumuskan hipotesis sebagai berikut:

$\mathrm{H}_{2}$ : Obsesi pada kualitas berpengaruh positif signifikan terhadap kepuasan pelanggan.

Team work bisa diartikan sebagai kerja tim atau kerjasama, team work atau kerja sama tim merupakan bentuk kerja kelompok dengan keterampilan yang saling melengkapi serta berkomitmen untuk mencapai misi yang sudah disepakati 
sebelumnya untuk mencapai tujuan bersama secara efektif dan efisien. Harus disadarai bahwa team work merupakan peleburan berbagai pribadi yang menjadi satu pribadi untuk mencapai tukian bersama. Sebuah tim itu sangat membutuhkan kemauan untuk saling bergandengan-tangan menyelesaikan pekerjaan. Apabila kerjasama tim sudah baik dan menghasilkan kinerja karyawan yang baik hal ini akan membuat pelanggan puas dengan kerja tim yang bagus. Kerjasama tim dalam sebuah organisasi merupakan komponen penting dalam Total Quality Management, mengingat kerja tim dapat meningkatkan kepercayaan diri, komunikasi dan mengembangkan kemandirian. Kerjasama tim dalam menangani proyek perbaikan atau pengembangan mutu pendidikan merupakan salah satu bagian dari pemberdayaan (empowerment) pegawai dan kelompok kerjanya dengan pemberian tanggung jawab yang lebih besar. Menurut Joiner (2007) rekan kerja yang mendukung dengan mudah berbagi informasi dan keahlian yang sesuai dengan tugas yang mungkin diartikan dengan penerapan Total Quality Management yang berhasil. Jika kerja tim dirasa cocok atau bahkan melebihi ekspektasi pelanggan terhadap pelayanan, mereka akan merasa puas.

Eksistensi kerjasama dalam sebuah bisnis sebagai modal utama dalam meraih mutu dan kepuasan stakeholders melalui proses perbaikan mutu secara berkesinambungan. Kerjasama tim mampu mencapai kinerja atau produktivitas yang diharapkan apabila dilakukan dengan adanya peran dan tanggungjawab yang jelas, mampu melaksanakan manajemen konflik, adanya prosedur operasi yang jelas dan simple, serta pencapaian misi tim. Penelitian yang dilakukan oleh Mahami (2015), Lopresti (2006), Kurniawati (2011), Efendi dan Mandala (2018) dan Andrianto dan Edo (2011) menyimpulkan bahwa kerjasama tim berpengaruh terhadap kepuasan pelangan, berdasarkan uraian berikut dapat dirumuskan hipotesis sebagai berikut.

$\mathrm{H}_{3}$ : Kerjasama tim berpengaruh positif signifikan terhadap kepuasan pelanggan.

Konsep perbaikan berkesinambungan diterapkan baik terhadap proses maupun orang yang melaksanakannya. Perbaikan yang terus menerus (continuous improvemen), yaitu memberikan tekanan pada perspektif yang sistematik, terpadu, konsisten, dan mencakup operasi seluruh organisasi perusahaan. Pendekatan ini hanya dapat berhasil dengan baik apabila disertai dengan usaha sumber daya manusia yang tepat. Faktor manusia merupakan dimensi yang terpenting dalam perbaikan kualitas dan produktivitas (Tjiptono dan Diana, 2014)

Unsur perbaikan berkelanjutan melibatkan komitmen untuk terus memeriksa proses teknis dan administratif untuk metode yang lebih baik (Koh \& Low, 2010) Proses perbaikan ini berbanding lurus dengan kompetensi, komitmen dan kerja tim serta organisasi untuk terus mengembangkan mutu dan kinerja perusahaan. Total konsep penerapan manajemen mutu bertujuan untuk memenuhi kebutuhan konsumen dengan perbaikan terus menerus. Perbaikan terus-menerus memiliki dua manfaat (Fayzollahi et al., 2013): 1) terhadap pelanggan karena dapat memenuhi keinginan mereka, dan 2) sebagai mekanisme yang dapat menghilangkan kerugian sehingga meminimalisasi pemborosan.

Penelitian yang dilakukan oleh Timor et al. (2018) menyatakan bahwa perbaikan berkesinambungan berpengaruh positif terhadap kepuasan pelanggan, berdasarkan uraian tersebut dapat dirumuskan hipotesis sebagai berikut. 
$\mathrm{H}_{4}$ : Perbaikan Berkseinambungan berpengaruh positif signifikan terhadap kepuasan pelanggan

\section{METODE PENELITIAN}

Penelitian ini menjelaskan pengaruh implementasi Total Quality Management yaitu variable fokus pada pelanggan, obsesi terhadap kualitas, kerjasama tim dan perbaikan berkesinambungan terhadap kepuasan pelanggan Kober Mie Setan cabang Pulau Kawe. Gedung Kober Mie Setan tempat penelitian dilaksanakan berada di Jalan Pulau Kawe No. 2, Dauh Puri Klod, Denpasar Barat, Kota Denpasar. Penentuan lokasi didasarkan atas beberapa pertimbangan antara lain: kompleksitas permasalahan atau potensi data yang dapat diperoleh untuk bisa dijadikan sebagai variabel-variabel yang diperlukan untuk mendukung pembuktian teori atau asumsi yang telah disusun. serta lokasi dan kondisi manajemen Kober mie setan yang relatif mudah diakses oleh peneliti untuk mendapatkan data yang diperlukan.

Objek dalam penelitian ini adalah kepuasan pelanggan, khususnya pelanggan pada rumah makan Kober Mie Setan. Kepuasan pelanggan adalah tingkat perasaan konsumen setelah membandingkan kinerja pelayanan yang dirasakan dibandingkan dengan harapannya. Menurut Citraluki (2016) dan setelah dimodifikasi dengan tempat penelitian Kober Mie Setan maka indikator kepuasan pelanggan adalah sebagai berikut. 1). Perasaan puas setelah membeli Kober Mie Setan (Y1); 2). Perasaan puas dengan harga dan kualitas yang diberikan Kober Mie Setan (Y2); 3). Perasaan puas atas perhatian dan pelayanan yang di berikan oleh karyawan Kober Mie Setan (Y3); 4). Perasaan pusa terhadap cita rasa jenis makanan dan minuman yang dimiliki Kober Mie Setan (Y4); 5). Perasaan puas dengan variasi jenis makan dan minuman yang dimiliki Kober Setan (Y5)

Fokus pada pelanggan adalah sikap dan perilaku Kober Mie Setan dalam memberikan pelayanan yang baik kepada pelanggan. Menurut Elvirawati (2013) (2013) dan setelah dimodifikasi dengan tempat penelitian Kober Mie Setan maka indikator focus pada pelanggan adalah sebagai berikut. 1). Interaksi antara karyawan dengan pelanggan pada saat pembayaran dikasir $\left.\left(\mathrm{X}_{1.1}\right) ; 2\right)$. Interaksi antara karyawan dengan pelanggan pada saat melayani pelanggan $\left.\left(\mathrm{X}_{1.2}\right) ; 3\right)$. Interaksi antara karyawan dengan pelanggan pada saat memberikan informasi $\left(\mathrm{X}_{1.3}\right)$; 4). Interaksi antara karyawan dengan pelanggan pada saat ada pertanyaan dari pelanggan $\left(\mathrm{X}_{1.4}\right)$.

Obsesi terhadap kualitas adalah upaya meningkatkan mutu rumah makan Kober Mie Setan sehingga bisa memenuhi harapan atau keinginan pelanggan. Menurut Rahman (2011) dan setelah dimodifikasi dengan tempat penelitian Kober Mie Setan maka indikator obsesi terhadap kualitas adalah sebagai berikut. 1). Keramahan dan kesopanan karyawan Kober Mie Setan dalam melayani pelanggan $\left(\mathrm{X}_{2.1}\right)$;2). Produk Kober Mie Setan dihidangkan menarik $\left.\left(\mathrm{X}_{2.2}\right) ; 3\right)$. Kesabaran karyawan Kober Mie Setan dalam memenuhi keinginan pelanggan $\left(\mathrm{X}_{2.3}\right)$; 4). Kober Mie Setan memiliki tempat parkir yang cukup $\left(\mathrm{X}_{2.4}\right)$; 5). Produk Kober Mie Setan memiliki rasa yang khas $\left.\left(\mathrm{X}_{2.5}\right) ; 6\right)$. Produk Kober Mie Setan terjamin higienis $\left(\mathrm{X}_{2.6}\right)$ 
Kerjasama tim adalah kerjasama karyawan kober mie setan dengan keterampilan masing-masing yang saling melengkapi serta berkomitmen untuk mencapai tujuan bersama yaitu memuaskan pelanggan kober mie setan. Menurut Mahami (2015) dan setelah dimodifikasi dengan tempat penelitian Kober Mie Setan maka indikator kerjasama tim adalah sebagai berikut. 1). Keseragaman jawaban yang diberikan oleh karyawan Kober mie setan atas pertanyaan konsumen (X3.1); 2). Kerjasama antar karyawan dalam memberikan pelayanan (X3.2); 3). Karyawan kober mie setan bertanggung jawab terhadap pekerjaan masing-masing (X3.3); 4). Terjadi kerjasama yang baik antar karyawan (X3.4); 5). Terjalin keakraban antar karyawan (X3.5).

Menurut Fitriasari (2017) dan setelah dimodifikasi dengan tempat penelitian Kober Mie Setan maka indikator perbaikan berkesinambungan adalah sebagai berikut. 1). Kober mie setan menindak lanjuti keluhan dari konsumen (X4.1);2) Adanya kelengkapan fasilitas seperti ruang tunggu, toilet dan tempat ibadah (X4.2); 3). Adanya fasilitas pengaduan terhadap keluhan atau komplain (X4.3); 4). Kemudahan dalam menyampaikan keluhan atau komplain (X4.4)

Teknik analisis data yang digunakan dalam penelitian ini adalah Regresi Linier Berganda namun sebelum dilakukan uji regresi berganda dilakukan terlebih dahulu yakni uji vailiditas dan reliabilitas instrument dan uji asumsi klasik. Menurut Sugiyono (2013) Analisis regresi linier berganda, dirumuskan sebagai berikut.

$$
\mathrm{Y}=\alpha+\beta 1 \mathrm{X} 1+\beta 2 \mathrm{X} 2+\beta 3 \mathrm{X} 3+\beta 3 \mathrm{X} 4+\mathrm{e}
$$

Keterangan :

$$
\begin{array}{ll}
\mathrm{KP} & =\text { Kepuasan pengguna jasa } \\
\alpha & =\text { Konstanta } \\
\beta & =\text { Koefisien regresi } \\
\mathrm{X} 1 & =\text { Fokus pada pelanggan } \\
\mathrm{X} 2 & =\text { Obsesi terhadap kualitas } \\
\mathrm{X} 3 & =\text { Kerjasama tim (team work) } \\
\mathrm{X} 4 & =\text { Perbaikan berkesinambungan } \\
\mathrm{e} & =\text { Error }
\end{array}
$$

\section{HASIL DAN PEMBAHASAN}

Kober Mie Setan merupakan salah satu rumah makan yang berlokasi di Jalan Pulau Kawe Denpasar yang ramai di kunjungi setiap harinnya. Kober Mie Setan menyajikan kuliner unik, dengan mie setan sebagai produk utamannya. Mie Setan sendiri adalah kreasi dari cwie mie. Mie yang di gunakan adalah mie pasta yang di goreng dengan menggunakan sediit minyak. Produk ini menyajikan mie dangan rasa pedas berdasarkan beerapa level yang ditawarkan, yaitu 1-5, dimana setiap levelnya menunjukan tinggkat kepedasannya yaitu level 1 dengan menggunakan 12 cabai, level 2 dengan 25 cabai, level 3 dengan 35 cabai, level 4 dengan 45 cabai, level 5 dengan 60 cabai. Kemudian mie pedas tersebut disajikan dengan somay dan taburan daging. Terdapat pula menu mie tanpa cabai 
dinamakan Mie Angel, Mie tersebut diperuntukan untuk anak-anak dan yang tidak menyukai makanan pedas.

Selain makanan disediakan pula minuman sejenis cocktail, diantaranya: es pocong, es genderuo, es tuyul, es sundel bolong, dll. Nama unuk dari menu yang ditawarkan menjadikan sebuah daya Tarik bagi konsumen. Harga yang ditawarkan cukup terjangkau, yaitu berkisar Rp 10.000/porsi Mie Setan semua level dan Mie Angel serta untuk minumannya Rp 5.000-Rp 12.000, adapun menu pelengkap berkisar Rp10.000- Rp 12.000.

Sejarah Kober Mie Setan di pelopori oleh bapak Bambang awalnya pada tahun 2011 Bapak Bambang mendirikan bengkel di Jalan Bromo Kabupaten Malang. Seiring tahun demi tahun pelanggan bengkel tersebut mulai surut. Ketika beristirahat makan siang dengan menu mie pangsit salah satu karyawan dari pemilik bengkel tersebut bertengkar dengan salah satu temannya. Tanpa di sengaja mengeluarkan kata-kata "setan". Dari situlah pemilik bengkel tersebut mempunyai inspirasi untuk membuka kedai Mie Setan.

Berdasarkan hasil deskripsi persepsi responden terhadap variabel kepuasan pelanggan yang diukur dengan 5 indikator menunjukkan nilai rata-rata tertingi pada pernyataan karyawan Kober Mie Setan bekerjasama dengan baik saat memberikan pelayanan $\left(\mathrm{X}_{3.2}\right)$ dengan nilai rata-rata rata 3,67. Terdapat sebanyak 17 responden atau 11,3 persen menjawab sangat setuju, 70 responden atau 46,7 persen menjawab setuju, 60 responden atau 40 persen menjawab cukup setuju dan 3 responden atau 2 persen responden menjawab tidak setuju. Sedangkan nilai ratarata terendah pada pernyataan karyawan Kober Mie Setan memberikan jawaban yang seragam $\left(\mathrm{X}_{3.1}\right)$ dengan nilai rata-rata 3,53 . Terdapat sebanyak 14 responden atau 9,3 persen menjawab sangat setuju, 62 responden atau 41,3 persen menjawab setuju, 63 responden atau 42 persen menjawab cukup setuju dan 11 responden atau 7,3 persen menjawab tidak setuju. Indikator karyawan Kober Mie Setan bertangung jawab terhadap pekerajaannya $\left(\mathrm{X}_{3.3}\right)$ menyatakan sebanyak 16 responden atau 10,7 persen mejawab sangat setuju, 64 responden atau 42,7 persen menjawab setuju, 64 responden atau 42,7 persen menjawab cukup setuju dan 6 responden atau 4 persen menjawab tidak setuju. Pernyataan terjalin kerja sama yang baik antak karyawan $\left(\mathrm{X}_{3.4}\right)$ menyatakan sebanyak 15 responden atau 10 persen menjawab sangat setuju, 73 responden atau 48,7 persen menjawab setuju, 57 responden atau 38 persen menjawab cukup setuju dan 5 responden atau 3,3 persen menjawab tidak setuju. Pernyataan karyawan Kober Mie Setan akrab antar sesama karyawan $\left(\mathrm{X}_{3.5}\right)$ menyatakan sebanyak 20 responden atau 13,3 persen menjawab sangat setuju, 57 responden atau 38 persen menjawab setuju, 67 responden atau 46 persen menjawab cukup setuju dan 4 responden atau 2,7 persen responden menjawab tidak setuju.

Berdasarkan hasil deskripsi persepsi responden terhadap variabel kepuasan pelanggan yang diukur dengan 4 indikator menunjukkan nilai rata-rata tertingi pada pernyataan adanya kelengkapan fasilitas tempat tunggu, toilet dan tempat ibadah $\left(\mathrm{X}_{4.2}\right)$ dengan nilai rata-rata 4,00, terdapat sebanyak 44 responden atau 29,3 persen menyatakan sangat setuju, 62 responden atau 41,3 persen menyatakan setuju, 44 responden atau 29,3 persen responden menyatakan cukup setuju. Sedangkan nilai rata-rata terendah pada pernyataan Kober Mie Setan 
menyediakan tempat pengaduan keluhan $\left(\mathrm{X}_{4.3}\right)$ dengan nilai rata-rata 3,37 persen. Terdapat sebanyak 9 responden atau 6 persen menjawab sangat setuju, 52 responden atau 34,7 persen menjawab setuju, 75 responden atau 50 persen menjawab cukup setuju, dan 14 responden atau 9,3 persen menyatakan tidak setuju. Indikator Kober Mie Setan menindak lanjuti keluhan dari konsumen $\left(\mathrm{X}_{4.1}\right)$ menyatakan sebanyak 21 responden atau 14 persen responden menjawab sangat setuju, 85 responden atau 56,7 persen menjawab setuju, 44 responden atau 29,3 persen menjawab setuju. Indikator kemudahan dalam menyampaikan keluhan (X.4) menyatakan sebanyak 19 responden atau 12,7 persen menjawab sangat setuju, 53 responden atau 35,3 persen responden menjawab setuju, 66 responden atau 44 persen menjawab cukup setuju, 11 responden atau 7,3 persen menjawab tidak setuju dan 1 responden atau 0,7 persen menjawab sangat tidak setuju.

Berdasarkan hasil deskripsi persepsi responden terhadap variabel kepuasan pelanggan yang diukur dengan 5 indikator menunjukkan nilai rata-rata tertingi pada pernyataan pelayanan perasaan puas terhadap harga dan pelayanan yang diberikan $\left(\mathrm{Y}_{2}\right)$ dengan nilai rata-rata 4,8, terdapat sebanyak 120 responden atau 80 persen menyatakan sangat setuju, 30 responden atau 20 persen menyatakan setuju. Sedangkan rata-rata terendah pada pernyataan pelayanan kober mie setan cepat dan responsive $\left(\mathrm{Y}_{3}\right)$ serta pernyataan perasaan puas terhadap rasa produk makanan dan minuman $\left(\mathrm{Y}_{4}\right)$ dengan rata-rata 3,55. Pada pernyataan pelayanan cepat dan responsif terdapat 15 responden atau 10 persen menjawab sangat setuju, 58 responden atau 38,7 persen menjawab setuju, 71 responden atau 47 persen menjawab cukup setuju dan 6 responden atau 4 persen menjawab tidak setuju. Pada pernyataan perasaan puas terhadap rasa produk terdapat sebanyak 16 responden atau 10,7 persen menjawab sangat setuju, 59 responden atau 39,3 persen menjawab setuju, 66 responden atau 44 persen menjawab cukup setuju dan 9 responden atau 6 persen menjawab tidak setuju. Indikator puas setelah menikmati Kober Mie Setan $\left(\mathrm{Y}_{1}\right)$ menyatakan sebanyak 88 responden atau 58,7 persen menjawab sangat setuju dan 62 responden atau 41,3 persen menjawab setuju. Indikator pilihan makanan dan minuman yang bervariasi $\left(\mathrm{Y}_{5}\right)$ menyatakan 22 responden atau 14,6 persen menjawab sangat setuju, 54 responden atau 36 persen menjawab setuju, 67 responden atau 44,7 persen menjawab cukup setuju, 6 responden atau 4 persen menjawab tidak setuju dan 1 responden atau 0,7 persen responden menjawab sangat tidak setuju.

Uji pertama yang dilakukan yakni validitas dan reliabilitas. Uji ini dilakukan untuk mengetahui apakah instrument yang digunakan pada penelitian ini valid dan reliabel dalam menggambarkan situasi yang sesungguhnya. Suatu instrumen dikatakan valid apabila Pearson Correlation terhadap skor total di atas 0,30.

Berdasarkan Tabel 2. menunjukkan bahwa seluruh indikator dalam variabel fokus pada pelanggan, obsesi pada kualitas, kerjasama tim, perbaikan berkesinambungan, dan kepuasan pelanggan memiliki nilai Pearson Correlation yang lebih besar dari angka 0,30 sehingga seluruh indikator tersebut dikatakan telah memenuhi syarat validitas data.

Hasil uji reliabilitas instrumen pada penelitian ini disajikan pada tabel berikut yang menunjukkan bahwa kelima variabel penelitian memiliki koefisien 
cronbach's alpha yang lebih besar dari angka 0,60 sehingga pernyataan pada kuesioner tersebut dapat dikatakan reliabel.

Tabel 2.

Hasil Uji Validitas

\begin{tabular}{|c|c|c|c|}
\hline Variabel & $\begin{array}{l}\text { Indik } \\
\text { ator }\end{array}$ & Pearson Correlation & Keterangan \\
\hline Fokus pada & $\mathrm{X} 1.1$ & 0,693 & Valid \\
\hline Pelanggan & $\mathrm{X} 1.2$ & 0,683 & Valid \\
\hline \multirow[t]{3}{*}{ (X1) } & $\mathrm{X} 1.3$ & 0,789 & Valid \\
\hline & $\mathrm{X} 1.4$ & 0,759 & Valid \\
\hline & $\mathrm{X} 2.1$ & 0,410 & Valid \\
\hline Obsesi pada & $\mathrm{X} 2.2$ & 0,524 & Valid \\
\hline Kualitas & $\mathrm{X} 2.3$ & 0,638 & Valid \\
\hline \multirow[t]{4}{*}{$(\mathrm{X} 2)$} & $\mathrm{X} 2.4$ & 0,775 & Valid \\
\hline & $\mathrm{X} 2.5$ & 0,654 & Valid \\
\hline & X2.6 & 0,749 & Valid \\
\hline & $\mathrm{X} 3.1$ & 0,818 & Valid \\
\hline \multirow{4}{*}{$\begin{array}{c}\text { Kerjasama Tim } \\
\text { (X3) }\end{array}$} & $\mathrm{X} 3.2$ & 0,747 & Valid \\
\hline & X3.3 & 0,737 & Valid \\
\hline & X3.4 & 0,704 & Valid \\
\hline & X3.5 & 0,691 & Valid \\
\hline Perbaikan & $\mathrm{X} 4.1$ & 0,662 & Valid \\
\hline \multirow{4}{*}{$\begin{array}{c}\text { Berkesinambungan } \\
\text { (X4) }\end{array}$} & $\mathrm{X} 4.2$ & 0,683 & Valid \\
\hline & $\mathrm{X} 4.3$ & 0,599 & Valid \\
\hline & $\mathrm{X} 4.4$ & 0,507 & Valid \\
\hline & Y.1 & 0,527 & Valid \\
\hline Kepuasan & Y.2 & 0,478 & Valid \\
\hline Pelanggan & Y.3 & 0,734 & Valid \\
\hline \multirow[t]{2}{*}{$(\mathrm{Y})$} & Y.4 & 0,754 & Valid \\
\hline & Y.5 & 0,677 & Valid \\
\hline
\end{tabular}

Sumber: data diolah, 2018

Tabel 3.

Hasil Uji Reliabilitas

\begin{tabular}{ccc}
\hline Variabel & $\begin{array}{c}\text { Cronbach's } \\
\text { Alpha }\end{array}$ & Keterangan \\
\hline Fokus pada Pelanggan (X1) & 0,710 & Reliabel \\
Obsesi pada Kualitas (X2) & 0,689 & Reliabel \\
Kerjasama Tim (X3) & 0,793 & Reliabel \\
Perbaikan Berkesinambungan (X4) & 0,626 & Reliabel \\
Kepuasan Pelanggan (Y) & 0,640 & Reliabel \\
\hline
\end{tabular}

Sumber: Data diolah, 2017

Berdasarkan perhitungan analisis regresi linear berganda, maka didapatkan hasil persamaan regresi sebagai berikut:

$$
Y=4,442+0,342 X_{1}+0,133 X_{2}+0,281 X_{3}+0,165 X_{4}
$$

Berdasarkan Tabel 4. pada kolom standardized coefficients menunjukkan bahwa nilai Beta pada variabel Fokus pada pelanggan sebesar 0,379, obesesi terhadap kualitas sebesar 0,182 , kerjasama tim sebesar 0,360 dan perbaikan 
berkesinambungan sebesar 0,142 , Variabel fokus pada pelanggan mempunyai nilai Beta paling besar yaitu 0,379 , artinya bahwa variabel fokus pada pelanggan merupakan variabel yang paling dominan dibandingkan dengan variabel yang lainnya. Variabel dengan nilai Beta terbesar ke dua dengan nilai beta sebesar 0,360 yaitu variabel kerja sama tim, variabel dengan nila Beta terbesar ke tiga dengan nilai 0,182 yaitu variabel obsesi terhadap kualitas dan variabel dengan nilai Beta yang paling rendah ditunjukkan oleh variabel perbaikan berkesinambungan dengan nilai Beta sebesar 0,142.

Tabel 4.

Hasil Uji Analisis Regresi Linier Berganda

\begin{tabular}{|c|c|c|c|c|c|}
\hline \multirow[t]{2}{*}{ Model } & \multicolumn{2}{|c|}{$\begin{array}{l}\text { Unstandardized } \\
\text { Coefficients }\end{array}$} & \multirow{2}{*}{$\begin{array}{r}\text { Standardizd } \\
\text { Coefficients }\end{array}$} & \multirow[t]{2}{*}{$\mathbf{t}$} & \multirow[t]{2}{*}{ Sig. } \\
\hline & B & $\begin{array}{c}\text { Std. } \\
\text { Error }\end{array}$ & & & \\
\hline (Constant) & 4.442 & 0,951 & & 4,670 & 0,00 \\
\hline $\mathrm{X}_{1}$ & 0,342 & 0,052 & 0,379 & 6,590 & 0,00 \\
\hline $\mathrm{X}_{2}$ & 0,133 & 0,041 & 0,182 & 3,205 & 0,02 \\
\hline$X_{3}$ & 0,281 & 0,049 & 0,360 & 5,756 & 0,00 \\
\hline $\mathrm{X}_{4}$ & 0,165 & 0,055 & 0,142 & 3,021 & 0,03 \\
\hline $\mathrm{R}$ & 0,855 & & & & \\
\hline $\mathrm{R}^{2}$ & 0,731 & & & & \\
\hline $\mathrm{F}$ & 98,534 & & & & \\
\hline F Sig. & 0,000 & & & & \\
\hline
\end{tabular}

Persamaan regresi dapat diartikan, konstanta (a) sebesar 4,442 artinya jika variabel Fokus pada pelanggan $\left(\mathrm{X}_{1}\right)$, Obesei terhadap kualitas $\left(\mathrm{X}_{2}\right)$, Kerjasama tim $\left(\mathrm{X}_{3}\right)$ dan Perbaikan Berkesinambungan $\left(\mathrm{X}_{4}\right)$ nilainya adalah 0 , maka kepuasan pelanggan (Y) nilainya sebesar 4,442. Koefisien regresi variabel Fokus pada pelanggan $\left(\mathrm{X}_{1}\right)$ sebesar 0,342 artinya jika fokus pada pelanggan naik 1 satuan maka kepuasan pelanggan akan mengalami peningkatan 0,342 satuan. Koefisien regresi variabel Obesei terhadap kualitas $\left(\mathrm{X}_{2}\right)$ sebesar 0,133 artinya jika obsesi terhadap kualitas naik 1 satuan maka kepuasan pelanggan akan mengalami peningkatan 0,133 satuan. Koefisien regresi variabel kerjasama tim $\left(\mathrm{X}_{3}\right)$ sebesar 0,281 artinya jika kerjasama tim naik 1 satuan maka kepuasan pelanggan akan mengalami peningkatan 0,281 satuan. Koefisien regresi variabel perbaikan berkesinambungan $\left(\mathrm{X}_{4}\right)$ sebesar 0,165 artinya jika obsesi terhadap kualitas naik sebesar 1 satuan maka kepuasan pelanggan akan mengalami peningkatan 0,165 satuan.

Pengaruh variabel fokus pada pelanggan terhadap kepuasan pelanggan Kober Mie Setan. Variabel fokus pada pelanggan merupakan variabel yang mempunyai nilai standardized coefficients lebih besar dari variabel lainnya yaitu sebesar 0,379 artinya bahwa variabel fokus pada pelanggan mempunyai pengaruh paling kuat terhadap kepuasan pelanggan. Berdasarkan hasil yang diperoleh nilai koefisien Beta dari persamaan regresi sebesar 0,342 dengan tingkat signifikansi sebesar 0,000 lebih kecil dari 0,05 yang berarti Ho ditolak dan Ha diterima. Hal tersebut berarti bahwa variabel fokus pada pelanggan berpengaruh positif signifikan terhadap kepuasan pelanggan. 
Jadi, peningkatan fokus pada pelanggan akan menyebabkan kenaikan kepuasan pelanggan, sebaliknya menurunnya fokus pada pelanggan akan menyebabkan penurunan kepuasan pelanggan. Interaksi antara karyawan dengan pelanggan saat pembayaran dikasir, interaksi antara karyawan dengan pelanggan saat melayani pelanggan, interaksi antara karyawan dengan pelanggan saat memberikan informasi dan interaksi saat ada pertanyaan dari pelanggan, berpengaruh terhadap peningkatan kepuasan pelanggan. Indikator Interksi antara karyawan dengan pelanggan saat memberikan informasi merupakan indikator yang mempunyai nilai rata-rata yang paling besar diantara indikator fokus pada pelanggan yang lainnya.

Hasil penelitian ini sesuai dengan hasil penelitian sebelumnya yang dilakukan Jaafreh (2012), Efendi dan Mandala (2018) yang menyatakan bahwa fokus pada pelanggan berpengaruh positif terhadap kepuasan pelanggan.

Pengaruh variabel obsesi pada kualitas terhadap kepuasan pelanggan Kober Mie Setan. Variabel obsesi pada kualitas merupakan variabel yang mempunyai nilai standardized coefficients terbesar ketiga yaitu sebesar 0,182 artinya bahwa variabel obsesi pada kualitas mempunyai pengaruh cukup kuat terhadap kepuasan pelanggan. Berdasarkan hasil yang diperoleh nilai koefisien Beta dari persamaan regresi sebesar 0,133 dengan tingkat signifikansi sebesar 0,002 lebih kecil dari 0,05 yang berarti Ho ditolak dan Ha diterima. Hal tersebut berarti bahwa variabel obsesi pada kualitas berpengaruh positif signifikan terhadap kepuasan pelanggan.

Jadi, peningkatan obsesi pada kualitas akan menyebabkan kenaikan kepuasan pelanggan, sebaliknya menurunnya obsesi pada kualitas akan menyebabkan penurunan kepuasan pelanggan. Keramahan dan kesopanan karyawan, hidangan yang menarik, kesabaran karyawan, tempat parkir memadai, rasa yang khas, dan produk yang higienis berpengaruh terhadap peningkatan kepuasan pelanggan. Indikator karyawan ramah dan sopan merupakan indikator yang mempunyai nilai rata-rata yang paling besar diantara indikator obsesi pada kualitas yang lainnya.

Hasil penelitian ini sesuai dengan hasil penelitian sebelumnya yang dilakukan oleh Elvirawati (2013), Mahami (2015), Efendi dan Mandala (2018) menyatakan bahwa obsesi pada kualitas berpengaruh positif terhadap kepuasan pelanggan.

Pengaruh variabel kerjasama tim terhadap kepuasan pelanggan Kober Mie Setan. Variabel kerjasama tim merupakan variabel yang mempunyai nilai standardized coefficients terbesar kedua setelah variabel fokus pada pelanggan yaitu sebesar 0,360 artinya bahwa variabel kerjasama tim mempunyai pengaruh yang kuat terhadap kepuasan pelanggan. Berdasarkan hasil yang diperoleh nilai koefisien Beta dari persamaan regresi sebesar 0,281 dengan tingkat signifikansi sebesar 0,000 lebih kecil dari 0,05 yang berarti Ho ditolak dan Ha diterima. Hal tersebut berarti bahwa variabel kerjasama tim berpengaruh positif signifikan terhadap kepuasan pelanggan.

Jadi, peningkatan kerjasama tim akan menyebabkan kenaikan kepuasan pelanggan, sebaliknya menurunnya kerjasama tim akan menyebabkan penurunan kepuasan pelanggan. Keseragaman jawaban yang diberikan, kerjasama antar 
karyawan dalam menyediakan perlengkapan, tanggung jawab masing-masing karyawan, kerjasama yang baik antar karyawan dan keakraban antar karyawan berpengaruh terhadap peningkatan kepuasan pelanggan. Indikator kerjasama antar karyawan dalam menyediakan perlengkapan bagi konsumen merupakan indikator yang mempunyai nilai rata-rata yang paling besar diantara indikator variabel kerjasama tim yang lainnya.

Hasil penelitian ini sesuai dengan hasil penelitian sebelumnya yang dilakukan oleh Mahami (2015), Lopresti (2006), Efendi dan Mandala (2018) dan Andrianto dan Edo (2011) menyatakan bahwa kerjasama tim berpengaruh positif terhadap kepuasan pelanggan.

Pengaruh veriabel perbaikan berkesinambungan terhadap kepuasan pelanggan Kober Mie Setan. Variabel perbaikan berkseinambungan merupakan variabel yang memiliki nilai standardized coefficients paling kecil dari variabel lainnya yaitu sebesar 0,142 artinya bahwa variabel obsesi pada kualitas mempunyai pengaruh paling lemah terhadap kepuasan pelanggan. Berdasarkan hasil yang diperoleh nilai koefisien Beta dari persamaan regresi sebesar 0,165 dengan tingkat signifikansi sebesar 0,003 lebih kecil dari 0,05 yang berarti Ho ditolak dan $\mathrm{Ha}$ diterima. Hal tersebut berarti bahwa variabel Perbaikan Berkesinambungan berpengaruh positif signifikan terhadap kepuasan pelanggan.

Jadi, peningkatan perbaikan berkesinambungan akan menyebabkan kenaikan kepuasan pelanggan, sebaliknya menurunnya perbaikan berkesinambungan akan menyebabkan penurunan kepuasan pelanggan. Menindak lanjuti keluhan, kelengkapan fasilitas, ruang tunggu toilet dan tempat ibadah, fasilitas pengaduan keluhan, kemudaha dalam menyampaikan keluhan berpengaruh terhadap peningkatan kepuasan pelanggan. Indicator kelengkapan vasilitas ruang tunggu toilet dan tempat ibadah merupakan indicator yang mempunyai nilai rata-rata paling besar diantara indicator variabel perbaikan berkesinambungan lainnya. Hasil Penelitian ini sesuai dengan hasil penelitian sebelumnya yang dilakukan oleh Mosahab et al. (2014) berpengaruh positif terhadap kepuasan pelanggan.

\section{SIMPULAN DAN SARAN}

Berdasarkan pembahasan hasil penelitian yang telah dilakukan, maka dapat diambil kesimpulan sebagai berikut. 1). Fokus pada pelanggan berpengaruh positif dan signifikan terhadap kepuasan pelanggan Kober Mie Setan, artinya semakin meningkat indikator fokus pada pelanggan seperti meningkatnya kecepatan dan keterampilan pelayanan saat dikasir, lebih cepat saat melayani pelanggan, memberikan informasi kepada pelanggan secara jelas dan lebih tanggap saat ada keluhan dari pelanggan maka kepusan pelanggan akan semakin meningkat. Variabel fokus pada pelanggan merupakan variabel yang paling dominan artinya variabel fokus pelanggan mempunyai pengaruh yang lebih kuat terhadap kepuasan pelanggan dibandingkan dengan variabel yang lainnya.; 2). Obsesi pada kualitas berpengaruh positif dan signifikan terhadap kepuasan pelanggan Kober Mie Setan, artinya semakin meningkat indikator obsesi pada kualitas seperti memperluas area parkir, karyawan lebih ramah dan sopan, lebih sabar dalam menangapi setiap keluham, produk yang bercitarasa khas, dan produk 
yang terjamin kehigienisannya maka kepuasan pelanggan akan semakin meningkat Obsesi terhadap kualitas merupakan variabel yang memiliki pengaruh kedua terbesar.; 3). Kerjasama tim berpengaruh positif dan signifikan terhadap kepuasan pelanggan Kober Mie Setan, artinya semakin meningkat indikator kerjasama tim seperti jawaban yang diberikan semakin kompak, kerjasama yang semakin baik, terjalin keakraban antar karyawan dan kerjasama antar karyawan saat menyedikan keperluan semakin baik maka kepuasan pelanggan akan semakin meningkat; 4). Perbaikan berkesinambungan berpengaruh positif dan signifikan terhadap kepuasan pelanggan Kober Mie Setan, artinya semakin meningkat indikator perbaikan berkesinambungan seperti menindak lanjuti keluhan, menyediakan tempat pengaduan keluhan, kemudahan menyampaikan keluhan yang dirasakan dan kelengkapan fasilitas maka kepuasan pelanggan akan semakin meningkat.

Saran yang dapat diberikan yakni fokus pada pelanggan mempunyai pengaruh paling dominan terhadap kepuasan pelanggan Kober Mie Setan, untuk itu pihak manajemen perusahaan Kober Mie Setan sebaiknya meningkatkan kemampuan karyawan dalam melayani pelanggan agar sikap dan perilaku karyawan bisa lebih baik lagi kepada pelanggan dengan cara memberikan arahan kepada karyawan sesuai dengan standar operasional perusahaan untuk dapat berinteraksi secara langsung dengan pelanggan dan melakukan tindakan yang diperlukan sebagai langkah untuk memberikan kepuasan pelanggan, misalnya selalu menawarkan bantuan kepada pelanggan serta menangani keluhan pelanggan. Perusahaan perlu mempertahankan obsesi terhadap kualitas yang dimilikinya, hal ini dapat dilakukan dengan cara menambah fasilitas penunjang lainnya seperti memperluas area parkir, mempertahankan keramahan serta kesopanan dari karyawan dalam melayani pelanggan dengan cara selalu tersenyum ketika melayani pelanggan, mempertahankan kebersihan dan kehigienisan produk Kober Mie Setan.

Kerjasama tim merupakan faktor yang mempengaruhi kepuasan pelanggan Kober Mie Setan, maka pihak manajemen Kober Mie Setan perlu meningkatkan kemampuan kerja karyawan, misalnya setiap karyawan sebaiknya menguasai kemampuan dalam tugasnya masing-masing dan bertindak cekatan dalam menjalankan pekerjaannya, kemampuan pengetahuan karyawan atas produk Kober Mie Setan seperti setiap karyawan mampu menjawab pertanyaan pelanggan mengenai harga, fasilitas dan pelayanan yang Kober Mie Setan dan selalu menjaga hubungan baik kantar karyawan. Perbaikan berkelanjutan mempengaruhi kepuasan pelanggan Kober Mie Setan, untuk itu pihak manajemen perusahaan Kober Mie Setan sebaiknya perlu untuk memperhatikan dan menindak lanjuti keluhan yang mungkin diutarakan oleh pelanggan dengan cara melakukan beberapa perbaikan maupun perawatan yang berkelanjutan pada fasilitas maupun sistem pelayanan yang ada. Sehingga diharapkan perusahaan bisa mendapatkan feedback positif dari pelanggan atau dengan kata lain kepuasan pelanggan dapat terpenuhi.

Penelitian berikutnya diharapkan bisa menambah variabel TQM yang lain seperti komitmen jangka panjang, pendidikan dan pelatihan, kebebasan yang terkendali, kesatuan tujuan dan keterlibatan dan pemberdayaan karyawan. Mampu 
mengembangkan model penelitian dan didukung dengan teori-teori maupun isuisu terbaru. Memberi pernyataan ataupun pertanyaan yang lebih spesifik disetiap indikator pada kuesioner. Memperluas wilayah penelitian dengan menambah cabang Kober Mie Setan yang diteliti serta menambah sample responden yang digunakan.

\section{REFERENSI}

Andrianto, Edo. (2011). Analisis Pengaruh Penerapan Total Quality Management Terhadap Kepuasan. (Studi Kasus Pada PT. Nasmoco Kaligawe Body Repair Semarang). Skripsi. Semarang: Universitas Diponegoro.

Amin, Muslim. 2016, Internet banking service quality and its implication on ecustomer satisfaction and e-customer loyality. Internasional Journal of Bank Marketing, 24 (3), pp. 280-306.

Arumugam.V, Hiaw Wei Chang, Keng-Boon Ooi, dan Pei-Lee Teh. 2009. Selfassessment of TQM practices: a case analysis. The Total Quality Management Journal, 21(1), pp. 46-58.

Citraluki, Jaeqline. 2016. Pengaruh Penerapan Total Quality Management (TQM) Terhadap Kepuasan Pelanggan Pada Indomaret Sekecamatan Kartasura Tahun 2016. Skripsi. Fakultas Ekonomi Universitas Muhammadiyah, Surakarta

Efendi, P., Mandala, K. (2018). Pengaruh Implementasi Total Quality Management Terhadap Kepuasan Pelanggan Pada Perusahaan Barjaz Di Denpasar. E-Jurnal Manajemen Universitas Udayana, 7(3), 1653.

Elvirawati. (2013). Pengaruh Penerapan Total Quality Management Terhadap Kepuasan Konsumen Pada Hotel Berbintang Di Daerah Istimewa Yogyakarta.

Fayzollahi, S., Shirmohammadi, A., Latifian, B. (2013). The impact of environmental factors on total quality management and firm performance: Evidence from industrial enterprises in Iran. International Research Journal of Applied and Basic Sciences, 4(10), 3237-3245.

Fitriasari, D. (2017). Analisis Tingkat Penerapan Total Quality Management (TQM) Perusahaan Roti di Sentra Industri Roti Desa Kalimalang Kabupaten Ponorogo. Skripsi. Fakultas Ekonomi Universitas Muhammadiyah Ponorogo.

Hassan, A.M, The basaltic soils of Plateau State, Nigeria: Properties, classification and management practices. Journal of Soil Science and Environmental Management, Vol. 6(1), pp. 1-8. 
Heizer, Jay and Barry Render. 2009. Operations Management (Manajemen Operasi). Jakarta Salemba Empat.

Hsing Liu, Chih, Sheng-Fang Chou, dkk. 2015. How "quality" determines customer satisfaction Evidence from the mystery shoppers' evaluation. The TQM Journal, 27 (5), pp. 576-590.

Jaafreh, A. B., \& Al-abedallat, A. Z. (2012). The Effect of Quality Management Practices on Organizational Performance in Jordan: An Empirical Study. International Journal of Financial Research, 4(1), 93-109.

Joiner, T. A. (2007). Total quality management and performance. International Journal of Quality \& Reliability Management, 24(6), 617-627.

Koh, T., \& Low, S. (2010). Title An empiricist framework for TQM implementation in construction companies Author ( s ) Koh, TY; Low, SP Citation Rights Journal of Management in Engineering . Copyright (C) American Society of Civil Engineers . AN EMPIRICIST FRAMEWORK FOR TQM IMPLEM. Journal of Management in Engineering, 26(3), 133143.

Kurniawati, A. (2011). Pengaruh Penerapan Total Quality Management (TQM) Terhadap Kepuasan Pelanggan Pada Hotel Pondok Asri Tawangmangun. (C).

Lopresti, R. (2006). Total Quality Management. Nursing Management (Springhouse), 24(1).

Mahami, C. (2015). . Pengaruh Penerapan Total Quality Management (TQM) dan Kualitas Layanan Terhadap Kepuasan Pelanggan di Hotel Sala View Surakarta, 151, 10-17.

Martono, C. dan Lena, E. 2012, "Pengaruh Implementasi Manajemen Kualitas Total Terhadap Kinerja Bisnis Perusahaan Manufaktur Menengah Dan Besar Di Jawa Timur: Komitmen Manajemen Sebagai Moderator", Media Mahardika 10 (Januari): hal. 67-104.

Mehra, Satish and Sampath Ranganathan. 2008. Implementing total quality management with a focus on enhancing customer satisfaction. International Journal of Quality \& Reliability Management, 25 (9), pp. 913-927

Mononimbar, C. N. (2013). Total Quality Management (TQM) Pengaruhnya Terhadap Kinerja Pelayanan Dan Kepuasan Konsumen Pada Pt. Taspen Manado. Jurnal EMBA, 1(3), 1041-1048.

Mosahab, R., Mahamad, O., Ramayah, T. (2014). Service Quality, Customer 
Satisfaction and Loyalty: a Test of Mediation. International Business Research, 3(4), 72-80.

Ooi, K. B., Lin, B., Tan, B. I., \& Chong, A. Y. L. (2011). Are TQM practices supporting customer satisfaction and service quality? Journal of Services Marketing, 25(6), 410-419.

RA Nur Amalina. (2015). Analisis pengaruh persepsi harga, kualitas layanan dan lokasi terhadap keputusan pembelian. Jurnal Manajemen, 4, 1-9.

Timor, H., Saud, U. S., Suhardan, D., Indonesia, U. P., Guru, K., \& Sekolah, M. (2018). Mutu sekolah: antara kepemimpinan kepala sekolah dan kinerja guru. Jurnal Administrasi Pendidikan, Vol.XXV No(1), 21-30.

Tjiptono, \& Diana. (2014). Total Quality Management (TQM). Yogyakarta: Andi.

Wuryanti, L. (2013). Tinjauan Manajemen Mutu Terpadu (Total Quality Management) dalam Meningkatkan Kepuasan Pelanggan. 2(2), 98-104. 